\title{
Effects of enoxaparin on the healing of abdominal wall in rats. Study on breaking strength and histopatology ${ }^{1}$
}

\author{
Efeitos da enoxaparina sobre a cicatrização da parede abdominal de ratos. Estudo da \\ força de ruptura e histopatológico
}

\author{
Paulo Gonçalves de Oliveira ${ }^{2}$, João Batista de Sousa ${ }^{2}$, Luiz Guilherme C. V. Reys ${ }^{3}$, Albino Verçosa de Magalhães ${ }^{4}$, \\ Francieli de Sousa Rabelo ${ }^{5}$, Karla Cardoso Muniz ${ }^{5}$
}

1. Research performed at the Experimental Surgery Laboratory, Faculty of Medicine, University of Brasília (UnB). Brazil.

2. MD, PhD, Associate Professor of Surgery, Faculty of Medicine, UnB. Brazil.

3. MD, Master in Surgery, Division of Surgical Clinics, UnB. Brazil.

4. MD, PhD, Full Professor of Pathology, Faculty of Medicine, UnB. Brazil.

5. Graduate Student, Faculty of Medicine, UnB. Brazil.

\begin{abstract}
Purpose: To evaluate the influence of enoxaparin on the abdominal wall healing. Methods: Sixty Wistar male rats were randomly distributed into two experimental groups. Group E: consisted of 30 rats, submitted to abdominal suture and treated with enoxaparin in a dose of $1 \mathrm{mg} / \mathrm{kg}$ of body weight, subcutaneously administered from immediate postoperative until the $7^{\text {th }}$ day; Group C: consisted of 30 rats submitted to abdominal suture and treated with the equivalent dose per volume of $\mathrm{NaCl} 0.9 \%$. The animals were submitted to median laparotomy and were operated again at the $3^{\text {rd }}$, $7^{\text {th }}$ or $14^{\text {th }}$ postoperative day for the resection of the anterior abdominal wall. The tissue's stretching resistance was tested and a histopathological evaluation was performed. Through Mann-Whitney's U test, a statistical analysis was conducted considering significant values for $\mathrm{p}<0.05$. Results: The tensile breaking strength presented a median of $0.64 \mathrm{~N}$ for group $\mathrm{C}$ and $0.41 \mathrm{~N}$ for group $\mathrm{E}(\mathrm{p}=0.60)$ at the $3^{\text {rd }}$ postoperative day; of $2.27 \mathrm{~N}$ for group $\mathrm{C}$ and of $4.32 \mathrm{~N}$ for group $\mathrm{E}(\mathrm{p}=0.01)$ at the $7^{\text {th }}$ POD; of $5.72 \mathrm{~N}$ for group $\mathrm{C}$ and of $6.62 \mathrm{~N}$ for group $\mathrm{E}(\mathrm{p}=0.97)$ at the $14^{\text {th }} \mathrm{POD}$. In relation to the histopathological study, the results did not show significant statistical differences, except for the amount of collagen at the $7^{\text {th }}$ POD, which medians were 2 on group $\mathrm{C}$ and 1 on group $\mathrm{E}(\mathrm{p}=0.007)$. Conclusion: Considering the conditions in which this study was conducted, the administration of enoxaparin led to an strengthening of the tissue's breaking resistance at the $7^{\text {th }}$ POD; on the histopathological exam, a significant difference was observed at the $7^{\text {th }}$ POD, with a better collagen disposition on group C.
\end{abstract}

Key words: Heparin, Low-Molecular-Weight. Enoxaparin. Anticoagulants. Abdominal Wall. Wound Healing. Rats.

\section{RESUMO}

Objetivo: Avaliar a influência da enoxaparina, sobre a cicatrização da parede abdominal. Métodos: Foram utilizados 60 ratos Wistar, distribuídos aleatoriamente em grupo estudo (E) e controle (C). O grupo E recebeu $1 \mathrm{mg} / \mathrm{kg}$ de enoxaparina, via subcutânea, do pós-operatório imediato até o $7^{\circ}$ dia pós-operatório (DPO); o grupo C doses-volume equivalentes de $\mathrm{NaCl}$ $0,9 \%$. Os animais foram submetidos à laparotomia mediana e reoperados no $3^{\circ}, 7^{\circ}$ ou $14^{\circ} \mathrm{DPO}$, para ressecção da parede abdominal anterior. A resistência tênsil foi testada e feita avaliação histopatológica. Análise estatística realizada com o teste U de Mann-Whitney, considerando significantes valores de $\mathrm{p}<0,05$. Resultados: A força tênsil de ruptura apresentou mediana de $0,64 \mathrm{~N}$ para grupo $\mathrm{C}$ e de $0,41 \mathrm{~N}$ para grupo $\mathrm{E}(\mathrm{p}=0,60)$ no $3^{\circ} \mathrm{DPO}$; de $2,27 \mathrm{~N}$ para grupo C e de $4,32 \mathrm{~N}$ para grupo $\mathrm{E}(\mathrm{p}=0,01)$ no $7^{\circ} \mathrm{DPO}$; de 5,72N para grupo C e de 6,62N para grupo $\mathrm{E}(\mathrm{p}=0,97)$ no $14^{\circ} \mathrm{DPO}$. Quanto ao estudo histopatológico, os resultados não obtiveram diferenças estatísticas significantes, exceto pela disposição do colágeno no $7^{\circ} \mathrm{DPO}$, cujas medianas foram 2 no grupo C e 1 no grupo E ( $p=0,007)$. Conclusão: Nas condições em que foi realizado o presente estudo, a enoxaparina provocou aumento da força tênsil de ruptura e pior disposição do colágeno no $7^{\circ} \mathrm{DPO}$.

Descritores: Heparina de Baixo Peso Molecular. Enoxaparina. Anticoagulantes. Parede Abdominal. Cicatrização de Feridas. Ratos.

\section{Introduction}

The healing process in defined as a series of events that starts with haemostasia and is followed by inflammatory response, conjunctive tissue formation and wound remodeling ${ }^{1,2,3}$. Several drugs are used in the postoperative period and may influence in the several healing phases.
Among these drugs, low molecular weigh heparins (LMWH) are widely used; however, their possible effects on the different healing phases and on tissue restoration are not yet fully clear.LMWH are recommended in the prevention of postoperative deep venous thrombosis and pulmonary embolism, especially in patients older than 40 years of age with additional risk factors for thrombosis and submitted to 
major surgeries ${ }^{6,7}$. Enoxaparin is a low molecular weigh heparin obtained through depolymerization of the nonfractioned heparin with production of fragments with molecular weigh ranging from 4,000 to 6,000 daltons. This heparin presents high capacity to inhibit the Xa factor, weak anti-IIa or anti-thrombin activity, lower affinity for plasmatic and vascular proteins, endothelial cells, macrophages and platelets, granting higher availability and plasmatic half-life and reduction on the side effects associated with thrombocytopeny and risk of bleeding when compared to non-fractioned heparins ${ }^{6,7,8}$. Besides its anticoagulant action, heparin presents several biological activities such as antiinflammatory action, immunological modulation and activation of vascular endothelial growth factors, fibroblasts growth factors and epidermal growth associated to heparin, all vital for healing ${ }^{10,11,12,13}$. Heparin also regulates angiogenesis and presents a chemotactic effect for endothelial cells in human cells cultures by enhancing the growth factor activity resulting in stimulus to vascular neoformation 13,14,15,16. On the other hand, the antiinflammatory action of heparin could cause the same effects on healing already described for antiinflammatory, steroidal and non-steroidal agents such as reduction on the tensile strength of closed wounds, reduction on epithelization and inhibition of the wound contraction 2,3,4,5,7,17. The local process of coagulation produces a fibrin matrix very important for healing, once the systemic desfibrinogenation delays the tensile strength development ${ }^{18}$. Once heparin is a powerful anticoagulant, a delay on healing as a result of the theoretical decrease on the fibrin deposition on the wound could be expected. Heparins may present several effects on the different healing phases, and it is not simple to establish which effect is determinant in the process. Therefore, the potential effects of heparins and their fragments in the surgical trauma and in the healing of wounds are very important.

\section{Methods}

The present study was submitted and approved by the Ethic Committee of Researches involving Animals and developed in the Experimental Surgery Laboratory of the Department of Clinical Surgery, Faculty of Medicine, University of Brasília (UnB). Sixty male Rattus norvegicus Wistar rats, apparently healthy, with initial weight between 330 and $500 \mathrm{~g}$ and between 90 and 120 days of age provided by Laboratório Bioagri Ltda were used. In the immediate postoperative period, the animals were kept in fast for 6 hours and with free access to water. Before surgical intervention, the animals had their weight measured. The animals were intramuscularly (IM) anesthetized with xilasin and ketamin with following trichotomy of the anterior abdominal wall and anti-sepsis of skin with iodinepolyvinylpirrolidone solution. Later, a 4 cm-length median laparotomy was performed with its caudal extremity at 0.5 $\mathrm{cm}$ from the external genitalia of the animal and synthesis of the abdominal wall into two levels; one involving the peritoneum, muscle and aponeurosis of the median line with simple continuous suture using 3-0 nylon string with cylindrical needle and the second, the subcutaneous tissue and skin, with suture performed as a Greek fret with 4-0 cotton string using sharp-edged needle. After surgical intervention, the animals were randomly distributed into two groups (each group with 30 rats) as follows: group $\mathrm{C}$ (control) and group E (experimental). In the postoperative period, the animals from group E received subcutaneous (SC) enoxaparin diluted in bidistilled water for the concentration of $1 \mathrm{mg} / \mathrm{ml}$ shortly after anesthetic procedure and the dose of $1 \mathrm{mg} / \mathrm{kg} /$ day each 24 hours in the postoperative period for up to 7 days. Animals from group $\mathrm{C}$ received equivalent subcutaneous dose/volume of $\mathrm{NaCl}$ $0.9 \%$ with the same administration parameters as the previous group. During this period, the animals were evaluated for the appearance of abdominal distention, diarrhea, apathy, wound dehiscence, hematomas and phlogistic signs in the operative wound. The animals from each group were randomly distributed according to the moment scheduled for euthanasia into subgroups of 10 animals called as groups $\mathrm{C}_{3}, \mathrm{C}_{7}, \mathrm{C}_{14}, \mathrm{E}_{3}, \mathrm{E}_{7}, \mathrm{E}_{14}$. Inscriptions 3,7 and 14 determine the euthanasia of animals at the third, seventh and fourteenth postoperative days (POD), respectively. In the day scheduled for euthanasia, the animals were weighted after anesthesia as for surgery, a fragment measuring $3 \mathrm{~cm} \times 3.5 \mathrm{~cm}$ was removed from the abdominal wall containing the scar in the middle part, being transversally divided into three parts with $1 \mathrm{~cm} \mathrm{x} 3.5 \mathrm{~cm}$. The cranial extremity was fixed in cardboard and set in $10 \%$ formaldehyde for histopatological study. The median segment was submitted to the tensile strength test in standardized tensiometer. The caudal extremity was discarded. At the end of the procedure, the euthanasia was performed through section of the inferior vena cava. The breaking strength study was evaluated through computerized analysis of data obtained in constant strength tensiometer with traction capacity of 2,500 N (Vertical Assay Machine Versa Test Mecmesin connected to digital dynamometer AGF Panambro Industria e Técnica S.A. $S P)$. The pieces previously fixed in formaldehyde were prepared according to protocol for confection of slides of the Pathology Laboratory - Medical School (UnB) and hematoxylin-eosin stained. The slides were analyzed by independent observer who ignored from which group the material was obtained. Semi-quantitative values were attributed to the following parameters: amount of fibroblasts, the value zero is attributed for the minimum amount of fibroblasts and four for maximum amount of fibroblasts; disposition of fibroblasts, with zero for maximum fibroblasts coiling and four for maximum horizontalization; maturation, with zero for scars with maximum amount of fibroblasts in relation to fibrocites, with minimum equal to zero and maximum equal to four; vascular neoformation, with zero for the less vascularized scar and four for the most vascularized scar; infiltration, with zero for scars with minimum amount of cellular infiltrate and four for maximum amount. The statistical analysis of the results obtained was performed by means of the SigmaStat ${ }^{\circledR}$ program version 2.0, using the Mann-Whitney's U test for the analysis of weight percentile variations, tensile strength and histopathological analysis in each subgroup. In all tests, the critical level from which differences were considered as significant was of $5 \%(\mathrm{p}<0.05)$. 


\section{Results}

\section{Animals’ clinical evolution}

Group E presented two animals (6.7\%) with apathy at the $1^{\text {st }}$ POD and two animals (6.7\%) with diarrhea, characterized by the presence of softened feces at the perianal region at least once during the period. An obit was verified at the $1^{\text {st }}$ POD of an animal from group $C$. The necropsy of the animal was performed and the following was verified: bilateral pleural hemorrhage and the presence of coagulum in the heart's right atrium. At the moment of euthanasia, the presence of abscess in the abdominal wall of one animal (3.3\%) from group C and in one animal (3.3\%) from group $\mathrm{E}$ was observed, both at the $7^{\text {th }}$ POD. The presence of internal hernia in one animal from subgroup E14 was also observed. No dehiscence of the abdominal wall, phlogistic signs or hematoma in the operative wound were observed. The weight percentile variation in the different groups between the day of euthanasia and surgery may be observed in Figure 1.

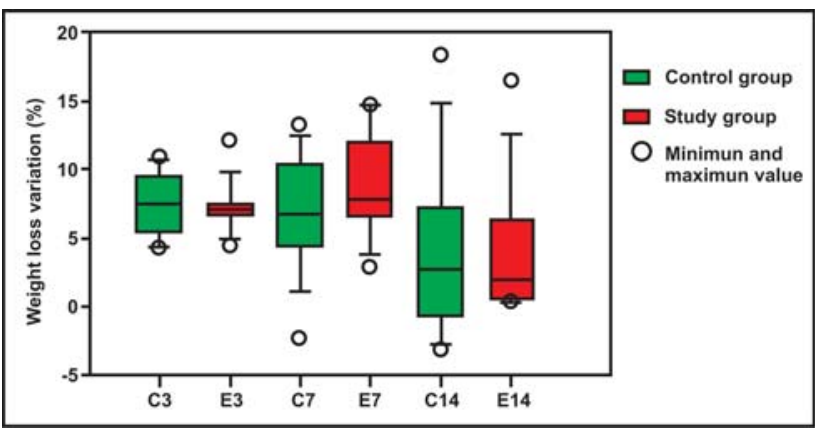

FIGURE 1 - Average and standard deviation of the weight loss variation (\%) according to subgroup: $3^{\text {rd }}$, $7^{\text {th }}$ and $14^{\text {th }}$ postoperative days $-\mathrm{p}<0.05$

\section{Tensile breaking strength}

Comparisons of the tensile breaking strength between the different subgroups may be observed in Figures 2, 3 and 4.

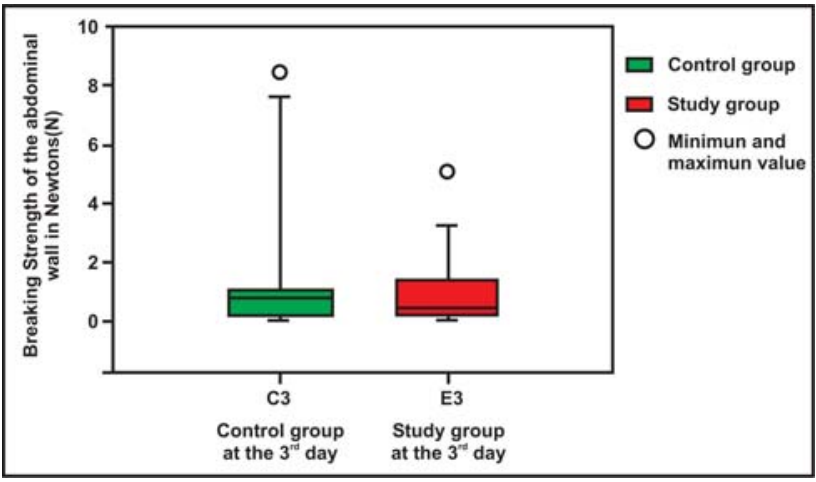

FIGURE 2 - Average and standard deviation of the tensile breaking strength in control and study groups at the $3^{\text {rd }}$ postoperative day $-\mathrm{p}<0.05$

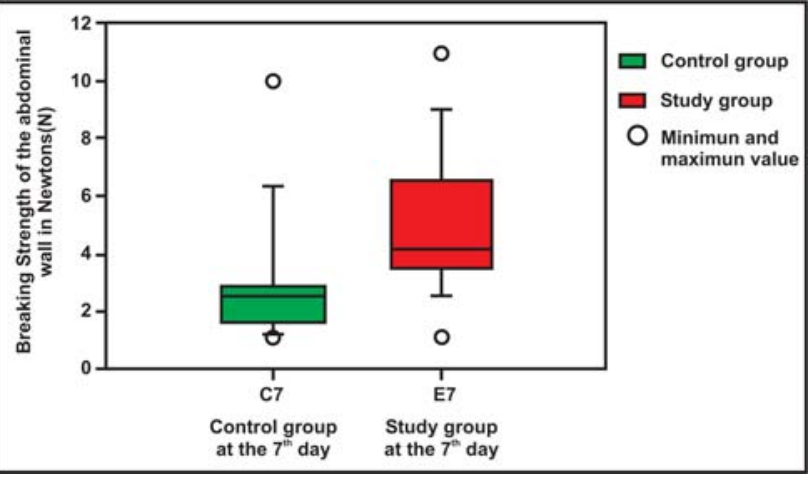

FIGURE 3 - Average and standard deviation of the tensile breaking strength in control and study groups at the $7^{\text {th }}$ postoperative day $-p<0.05$

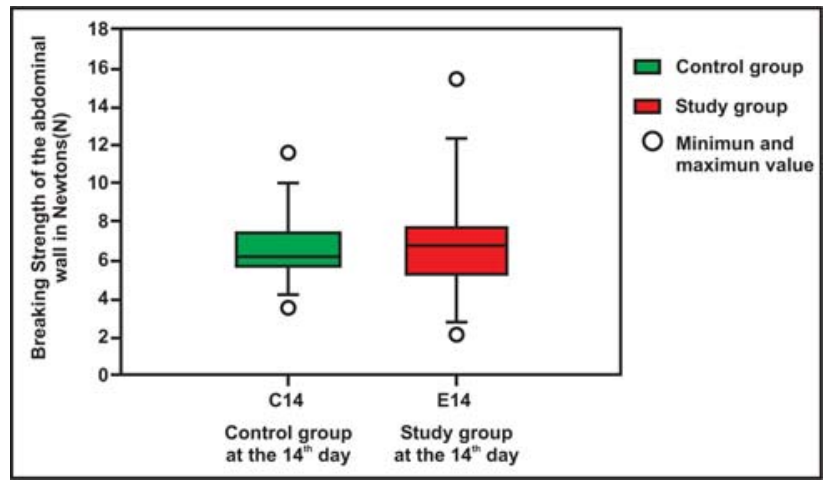

FIGURE 4 - Average and standard deviation of the tensile breaking strength in control and study groups at the 14th postoperative day $-\mathrm{p}<0.05$

\section{Histopathological analysis}

The results concerning the histopathological evaluation of the muscle-aponeurotic healing process in relation to quantity, disposition and maturation of fibroblasts, inflammatory infiltrate and vascularization compared between control and study groups submitted to euthanasia at the same postoperative day are found in Tables 1,2 and 3. 
TABLE 1 - Histopathological indicatives in groups C3 and E3

\begin{tabular}{lcccc}
\hline & C3 & Medians & Minimum - \\
& & $\mathrm{E} 3$ & $\mathrm{p}$ & $1-3$ \\
maximum values
\end{tabular}

TABLE 2 - Histopathological indicatives in groups C7 and E7

\begin{tabular}{lcccc}
\hline & C7 & Medians & P7 & $\begin{array}{c}\text { Minimum - } \\
\text { maximum values }\end{array}$ \\
\hline Amount of fibroblasts & 2 & 3 & 0.19 & $1-3(\mathrm{C}) / 2-3(\mathrm{E})$ \\
Disposition & 2 & 1 & 0.007 & $1-3(\mathrm{C}) / 0-2(\mathrm{E})$ \\
Maturation & 2.5 & 2 & 0.27 & $1-3(\mathrm{C}) / 1-2(\mathrm{E})$ \\
Vascularization & 4 & 3 & 0.25 & $2-4(\mathrm{C}) / 1-4(\mathrm{E})$ \\
Infiltrate & 3 & 3 & 0.97 & $1-4$ \\
\hline
\end{tabular}

TABLE 3 - Histopathological indicatives in groups C14 and E14

\begin{tabular}{llllc}
\hline & C14 & Medians & & \\
& & $\mathrm{E} 14$ & $\mathrm{p}$ & $\begin{array}{c}\text { Minimum }- \\
\text { maximum values }\end{array}$ \\
\hline Amount of fibroblasts & 1.5 & 2 & 0.31 & $1-3$ \\
Disposition & 3 & 2 & 0.14 & $1-3$ \\
Maturation & 3 & 2 & 0.09 & $2-3(\mathrm{C}) / 1-3(\mathrm{E})$ \\
Vascularization & 3 & 3 & 0.8 & $1-3$ \\
Infiltrate & 2 & 3 & 0.11 & $0-3(\mathrm{C}) / 1-4(\mathrm{E})$ \\
\hline
\end{tabular}

\section{Discussion}

The clinical evolution of the animals showed no significant alterations. Considering groups re-operated at different intervals, one observes higher weight loss for group treated with enoxaparin with euthanasia at the $7^{\text {th }}$ POD in relation to the control group; however, this difference was not significant. The analysis of the weight variation after surgical procedure showed similar values between control and study groups and no difference statistically significant was observed between them. Therefore, one infers that the procedure itself is the responsible for the weight loss. In the evaluation of the breaking strength of the abdominal wall of groups with same postoperative evolution period, values were similar between control and study groups sacrificed at the $3^{\text {rd }}$ and $14^{\text {th }}$ POD, and no significant differences were observed. At the $7^{\text {th }}$ POD, a higher breaking strength was observed for the study group in relation to the control one $(p=0.01)$. This fact could be explained by a better angiogenesis of rats treated with enoxaparin, once heparin is associated with the activation of fibroblasts growth factors, epidermal growth and especially vascular endothelial growth ${ }^{10,11,12,13}$. This latter would be the main factor for the vascular neoformation stimulus ${ }^{13,14,15,16}$. There are experimental studies reporting faster healing as a result of the better granulation tissue formation and collagen fibers in rats with $2^{\text {nd }}$ degree burns treated with subcutaneous heparin and improvement on angiogenesis and decrease on the healing time in patients with diabetic ulcer, ulcerative colitis and burns ${ }^{12,13,19,20}$. Matzsch et al. ${ }^{21}$ performed a study comparing the tensile strength in colonic anastomoses and in the abdominal wall of rats treated with LMWH during three or seven days and found a significant increase on the tensile strength in intestinal anastomoses in rats treated for up to 7 days, and no significant difference in the tensile strength of the abdominal wall was observed ${ }^{21}$. Scar is morphologically defined as a conjunctive tissue repair when there is no possibility of regeneration. The crossing between proliferating elements, fibroblasts and endothelial cells between both sides of the wound provides reasonable tensile strength, which justifies the removal of strings in a surgical intervention at the $7^{\text {th }}$ postoperative day. However, in this phase of the histopatological analysis, the healing tissue is still found quite disorganized and with a large number of cells and does not resemble the mature healing tissue composed of parallel collagen fibers with a little or no infiltrate, only observed months after surgical intervention ${ }^{2,3,4,5}$. The method used for the histopathological analysis is semiquantitative and, therefore, with some degree of subjectivity. In the histopathological analysis, a significant difference was observed for the group re-operated at the $7^{\text {th }} \mathrm{POD}$, with better collagen disposition for group $\mathrm{C}$ in relation to group $\mathrm{E}$. This result, which would firstly be conflicting with results obtained for the tensile strength, was no longer obtained and at the $14^{\text {th }} \mathrm{POD}$, the parameters analyzed presented no significant difference between groups, what leads us to conclude that enoxaparin did not influence the final healing maturation from the histopathological point of view. 


\section{Conclusion}

In the conditions in which the present study was conducted, the use of enoxaparin caused an increase on the tensile breaking strength and worse collagen disposition at the $7^{\text {th }}$ POD.

\section{References}

1. Tognini JRF, Fagundes DJ, Novo NF, Juliano Y. Estudo biomecânico e morfológico da cicatrização da parede abdominal sob ação de meloxicam. Acta Cir Bras. 2000; 15(3): 146-55.

2. Souza JAG, Barbosa H. Ferida operatória. In: Barbosa, H. Controle clínico do paciente cirúrgico. 6ed. Rio de Janeiro: Atheneu; 1992. p. 202-13.

3. Sousa JB, Oliveira PG. Cuidados com a ferida operatória: infecção. Clin Cir Bras. 1999, 5(2): 215-37.

4. Sousa JB, Soares EG, Aprilli F. Effects of diclofenac sodium on intestinal anastomotic healing. Experimental study on the small intestine of rabbits. Dis Colon Rectum. 1991; 34(7): 613-7.

5. Oliveira PG, Soares EG, Aprilli F. Influence of misoprostol, a synthetic prostaglandin E1 analog, on the healing of colonic anastomoses in rats. Dis Colon Rectum. 1994; 37(7): 660-3.

6. Majerus PW, Broze GJ, Miletich JP, Tollefsen DM. Fármacos anticoagulantes, trombolíticos e antiplaquetários. In: Hardman JG, Limbird LE. Goodman e Gilman: as bases farmacológicas da terapêutica. 9ed. Rio de Janeiro: Mc GrawHill; 1996. p.991-1005.

7. Pollack S. Wound healing. A review IV: systemic medications affecting wound healing. J Dermatol Surg Oncol. 1982; 8: 667-72.

8. Baruzzi ACA, Nussbacher A, Lagudis S, Souza JAM. Simpósio ABC de tromboembolismo pulmonar: trombose venosa profunda: profilaxia. Arq Bras Cardiol. 1996; 67(3): 215-18.

9. Holmer E, Soderberg K, Bergqvist D, Lindahl U. Heparin and its low molecular weight derivatives: anticoagulant and antithrombotic properties. Haemostasis. 1986; 16(2): 16-7.

10. Levine A, Kenet G, Bruck R, Avni Y, Avinoach I, Aeed H, Matas Z, David M, Yayon A. Effect of heparin on tissue binding activity of fibroblast growth factor and heparinbinding epidermal growth factor in experimental colitis in rats. Pediatr Res. 2002; 5(51): 635-40.
11. Street JT, McGrath M, O’Regan K, Wakai A, Mc Ginness A, Redmond HPR. Thromboprophylaxis using a low molecular weight heparin delays fracture repair. Clin Orthop Relat Res. 2000; 381: 278-89.

12. Michell NP, Lalor P, Langman MJ. Heparin therapy for ulcerative colitis? Effects and mechanisms. Eur J Gastroenterol Hepatol. 2001; 13(4): 449-56.

13. Galvan L. Effects of heparin on wound healing. J Wound Ostomy Continence Nurs. 1996; 23(4): 224-6.

14. Folkman J. Regulation of angiogenesis: a new function of heparin. Biochem Pharmacol. 1985; 34: 905-9.

15. Terranova VP, Diflorio R, Lyall RM, Hic S, Friesel R, Maciag T. Human endothelial cells are chemotactic to endothelial cell growth factor and heparin. J Cell Biol. 1985; 101: 2330-34.

16. Piazuelo E, Jiemenez P, Lanas A, Garcia A, Esteva F, Sainz R. Platelet-derived growth factor and epidermal growth factor play a role in human colonic fibroblastic repair. Eur Surg Res. 2000; 32(3): 191-6.

17. Minossi JG, Leite CVS, Naresse LE, Rodrigues MAM, Angeleli AYO, Kobayasi S. Efeitos do diclofenaco de sódio na cicatrização da parede abdominal de ratos: estudo histopatológico da força de ruptura e do colágeno tecidual. Acta Cir. Bras. 2001; 16(3): 146-54.

18. Brändstedt S. Wound healing and granulation tissue formation after desfibrinogenation. An experimental study in the rabbit. Thesis, University of Lund, 1980.

19. Jorneskog G, Brismar K, Fagrell B. Low molecular weight heparin seems to improve local capillary circulation and healing of chronic foot ulcers in diabetic patients. Vasa. 1993; 22(2): 137-42.

20. Saliba MJ. The effects and uses of heparin in the care of burns that improves treatment and enhances the quality of life. Acta Chir Plast. 1997; 39(1): 13-6.

21. Matzsch T, Bergqvist D, Blomquist P, Jiborn H. Influence of standard heparin or low molecular weight heparin on healing of abdominal wounds and colonic anastomoses in rats. Acta Chir Scand. 1987; 153(10): 593-8.

\section{Acknowledgements}

To the employees of the Animal Shelter and Experimental Surgery Laboratory of the Department of Surgical Clinics, Faculty of Medicine, UnB for their good willing and cooperation without which this research could not be successfully concluded.

\section{Correspondence:}

Paulo Gonçalves de Oliveira

Universidade de Brasília - Campus Universitário Darcy Ribeiro

Faculdade de Medicina

70910-900 Brasília-DF Brazil

pgofmunb@unb.br
Conflict of interest: none Financial source: none

Received: December 15, 2005

Review: January 17, 2006

Accepted: February 09, 2006

\section{How to cite this article:}

Oliveira PG, Sousa JB, Reys LGCV, Magalhães AV, Rabelo FS, Muniz KC. Effects of enoxaparin on the healing of abdominal wall in rats. Study on breaking strength and histopatology. Acta Cir Bras. [serial on the Internet] 2006 May-June 21(3). Available from URL: http://www.scielo.br/acb. 